\title{
Thermal disinfection of hospital wastewater in a pilot-scale continuous-flow system
}

\author{
K. M. Śmiech ${ }^{1}$-T. Kovács ${ }^{2}$ - R. F. Wildschut ${ }^{1}$ - A. J. Criado Monleon ${ }^{3}$ - B. de Vries-Onclin ${ }^{3}$ · J. G. Bowen ${ }^{4}$. \\ L. L. F. Agostinho'
}

Received: 6 January 2020 / Accepted: 17 March 2020 / Published online: 30 March 2020

(c) The Author(s) 2020

\begin{abstract}
Thermal disinfection is probably the oldest water treatment method ever used. Similarly to other disinfection processes, it targets the inactivation of pathogenic (micro)organisms present in water, wastewater and other media. In this work, a pilot-scale continuous-flow thermal disinfection system was investigated using highly contaminated hospital wastewater as influent without any pre-treatment step for turbidity removal. The results proved that the tested system can be used with influent turbidity as high as $100 \mathrm{NTU}$ and still provide up to $\log 8$ microbial inactivation. Further results have shown energy consumption comparable to other commercially available thermal disinfection systems and relatively low influence on the investigated physical-chemical parameters.
\end{abstract}

Keywords Thermal disinfection · Turbidity $\cdot$ Treatment technology $\cdot$ Water reclamation $\cdot$ Wastewater reuse

\section{Introduction}

Water is essential to life, but when contaminated, it can cause serious diseases such as diarrhea, cholera, dysentery, typhoid, polio or hepatitis A (Batra et al. 2018; Hatami 2013; Misra and Singh 2012; Pirsaheb et al. 2017). The Sustainable Development Goal target 6.1 aims at ensuring access to safe and affordable drinking water to the global population by 2030 (United Nations 2010). Significant progress has already been made, and between 2000 and 2016 the mortality rate related to diarrhea decreased by $59.3 \%$ among children under 5 years old and by $31.8 \%$ among the elderly older than 70 (GBD 2016 Diarrhoeal Disease Collaborators 2018). At the same time, the World Health Organization estimates that more than 2 billion people in the world still

K. M. Śmiech

karolina.smiech@hvhl.nl

1 Water Technology Research Group, NHL-Stenden University of Applied Sciences, Leeuwarden, The Netherlands

2 Van Hall Larenstein University of Applied Sciences, Leeuwarden, The Netherlands

3 Wetsus, European Centre of Excellence for Sustainable Water Technology, Leeuwarden, The Netherlands

4 Bowen H2O Technology Inc, Prescott, AZ, USA use drinking water sources contaminated with feces which leads to 485,000 annual deaths (WHO 2019). There are visible inequalities in access to safely managed drinking water, the most affected people being the poor inhabitants of rural areas in the least developed countries. According to UNICEF, in 2017 over 144 million people were still collecting their drinking water directly from rivers, lakes and ponds, more than a half of them living in sub-Saharan Africa (UNICEF and WHO 2019). Next to household-level usage, safe water is also needed for irrigation, food production, recreation, etc.

Predictions are that along with progressing climate change, increasing demographic pressure and industrialization, the necessity for water reclamation, including reuse of treated wastewater, will become more and more crucial for sustaining freshwater supplies in many regions (Garnier et al. 2015; Lavrnić et al. 2017; Tram Vo et al. 2014). In order to do that without compromising public health and ecosystem safety, proper treatment techniques need to be applied, including efficient, robust and inexpensive disinfection.

Many sources of reclaimed water are characterized by high turbidity. Such sources include not only treated wastewater (domestic, hospital, gray water, etc.) but also rainwater (Khayan et al. 2019; Lee et al. 2016) or water in disaster-struck areas (Basu et al. 2017; Sarkar and Vogt 2015). 
Commonly applied physical and chemical disinfection methods, such as chlorination or UV irradiation, require removal of turbidity prior to disinfection (EPA 2011; Metcalf and Eddy 2014). Turbidity above 1-2 NTU increases chlorine demand due to chemical reactions of chlorine and particulate matter (Keegan et al. 2012; Léziart et al. 2019). Lechevallier et al. (1981) developed a numerical model which predicts chlorine demand of a given water source as a function of turbidity. According to their model, the chlorine demand of waters with turbidities equal to 10,60 and 100 NTU is, respectively, 7, 40 and 70 times larger than chlorine demand of water with 1 NTU turbidity.

Next to consuming chlorine, particles can also shield microorganisms from inactivation, therewith further reducing the efficacy of chlorination (Winward et al. 2008), which, as exposed below, also decreases UV systems' efficiency. Further, the presence of organic matter increases the risk of formation of potentially harmful disinfection by-products (DBPs), such as trihalomethanes (THMs), haloacetic acids (HAAs) or $N$-nitrosodimethylamine (NDMA) (Du et al. 2017; Li and Mitch 2018). Additionally, before the treated water can be reclaimed for further use or returned back to the environment, the residual toxicity needs to be reduced by dechlorination (Metcalf and Eddy 2014). In the case of UV light, the reduced effectiveness of disinfection results from reduced UV light transmission and shielding of microorganisms from inactivation (Farrel et al. 2018; Kollu and Örmeci 2012; Metcalf and Eddy 2014).

Microorganism inactivation by heat is the oldest and simplest method of disinfection, applied for millennia in human households for food and drink preparation. Since 1862 when Louis Pasteur proved that heating of wine can prevent it from spoiling, thermal treatment has been widely used in food industry in a process called pasteurization (Currier and Widness 2018; Watts 2016). All over the world heat is also used to sterilize medical equipment and laboratory waste in autoclaves. According to the literature, such inactivation is based on three mechanisms: (1) denaturing of enzymes within the cell which leads to the loss of their functionality, (2) damage to the structure of proteins and fatty acids which constitute the cell wall and (3) expansion of fluids within the cell leading to the rupture of the cell wall and leakage of the cell components (Metcalf and Eddy 2014).

Thermal disinfection has been proven exceptionally effective against bacteria, protozoa and viruses, including those resistant to chemical treatment or irradiation (Al-Gheethi et al. 2013; Backer 1996; Ericsson et al. 2002; Corradini et al. 2007; Smelt and Brul 2014). In contrast to other widely applied methods, thermal disinfection does not lead to the formation of any known DBPs in measurable concentrations, it is characterized by high degree of penetration into particles and its efficiency is not affected by the presence of turbidity, natural organic matter (NOM), water hardness or pollutants such as metals (Metcalf and Eddy 2014; Thornton et al. 2006). Furthermore, thermal disinfection is chemicalfree and it is not expected to change water properties such as taste, smell, appearance or salinity (Ericsson et al. 2002). Additionally, application of heat can result in the destruction of heat-sensitive pharmaceuticals and hormones (Braekeveld et al. 2011; Heshmati 2015; Morais et al. 2018; Tian et al. 2017).

Scientific literature documents several cases of thermal disinfection. Abraham et al. (2015) presented a comprehensive discussion of solar thermal pasteurization of drinking water, including methodology, description of devices, microbiology and thermal analysis. Plourde et al. (2019) designed and evaluated a solar-powered thermal pasteurization system which can be applied at low ambient temperatures and low insolation. Reyneke et al. (2016) tested the efficiency of solar thermal pasteurization to reduce Legionella contamination of roof-harvested rainwater, while Spinks et al. (2006) investigated thermal inactivation of eight water-borne pathogens, including Enterococcus faecalis, Salmonella typhimurium and Klebsiella pneumonia, at sub-boiling temperatures. Al-Gheethi et al. (2013), Al-Gheethi et al. (2018) and MocéLlivina et al. (2003) focused their research on thermal disinfection of treated wastewater and waste sludge produced during wastewater treatment. Newman (2004), Orlikowski et al. (2017), Runia and Amsing (2001) and Tripanagnostopoulos and Rocamora (2007) described the use of a heat disinfection system for water reuse in horticulture.

Regarding the development of commercially available thermal disinfection systems for wastewater, the authors could find two examples, one described in a conference paper (Thornton et al. 2006) and the other widely presented in the online specialist resources (Godwin and McBurnett 2016; Chawaga 2015; Cox 2013). Thornton et al. (2006) proved that their system was capable of achieving at least log 4 disinfection of treated municipal wastewater and at least $\log 4$ disinfection of pig manure containing more than $15 \%$ solids. They also underlined the importance of efficient heat recovery in making their and similar systems commercially viable. The online sources (Godwin and McBurnett 2016; Chawaga 2015; Cox 2013) report commercial availability of a wastewater pasteurization system which can generate low-cost power in parallel with water treatment. The texts mention that the system was tested at municipal wastewater treatment plants in several cities in the USA and Australia as well as at a craft brewery in the USA. In all cases, satisfying disinfection levels were achieved and the disinfection process generated power which was reused at the respective plants and contributed to the reduction in their overall energy costs.

A common feature of the aforementioned thermal disinfection cases is that they all apply pasteurization, i.e., subboiling temperatures $\left(60-100{ }^{\circ} \mathrm{C}\right)$ and longer residence times 
(typically several minutes up to hours). Microorganisms become inactivated upon exposure to temperatures exceeding their growth optimum for a given exposure time, where the required exposure time depends on the temperature and microorganism type (Abraham et al. 2015). It has been shown that the necessary exposure time becomes drastically shorter as the operational temperature increases (Parry and Mortimer 1984; Pullman et al. 1981). The research presented in this article investigated a thermal disinfection method which uses high temperatures (140-160 ${ }^{\circ} \mathrm{C}$ ) and short exposure times (10 $\mathrm{min}$ ) to inactivate microorganisms. The primary goal was to establish whether this method can be successfully applied to disinfect water streams with high turbidity (60-100 NTU) and high level of microbial contamination $\left(10^{5}-10^{7} \mathrm{CFU} \mathrm{mL}^{-1}\right)$ without pre-treatment, i.e., just big solids removal, also to evaluate the impact of the process on physical-chemical parameters of the treated water. To achieve these goals, wastewater coming from a local hospital (high level of contamination) was used for the tests. The obtained results proved that high turbidity was not an obstacle for achieving high (up to $\log 8$ ) disinfection levels.

\section{Materials and methodology}

A pilot-scale continuous-flow heat and pressure disinfection system was used to treat wastewater discharged by Antonius Hospital in Sneek, the Netherlands. The operational principle of the tested system is based on the application of three factors: temperature, pressure and residence time (Śmiech et al. 2018). The temperature is set at a fixed value between 140 and $160{ }^{\circ} \mathrm{C}$. The applied pressure exceeds the saturated water partial pressure for a given temperature, to keep the treated water in its liquid form. The residence time is determined by the flow rate and needs to be long enough to achieve the desired level of microbial inactivation. In the current research, the temperature, pressure and flow rate in the disinfection system were constant and set at $140{ }^{\circ} \mathrm{C}, 7$ bar and $200 \mathrm{~L} \mathrm{~h}^{-1}$, respectively. The flow rate corresponded to a residence time of $10 \mathrm{~min}$.

To minimize energy usage, the pilot was designed with heat recovery (Fig. 1). Cold influent which enters the system through a copper pipe is first preheated via a heat exchanger by the hot effluent leaving the system. Subsequently, the treated water flows into the heating chamber. There, the copper pipe with the treated water is immersed in a high thermal capacity liquid which is maintained at the operational temperature. Such liquid is important for an energy-efficient operation because, once it has reached the working temperature, maintaining it requires a relatively low heat input.

The hospital wastewater was first pre-sieved $(3 \mathrm{~mm})$ and pre-filtered (0.5-mm drum filter) to remove larger solids. It was subsequently used to prepare three influents for the disinfection pilot: diluted wastewater (1:10 with tap water), electrocoagulation-treated (ECT) wastewater and raw wastewater (directly after pre-sieving and pre-filtration). It is important to mention that the main objective of this study was to verify the disinfection efficiency of the pilot system when treating waters with high turbidity. However, at the beginning of the research it was unclear how the system would react to the high particle content in wastewater and whether any operational problems would occur. Therefore, the experiments were planned with the three influents in the
Fig. 1 Schematic diagram of the pilot disinfection system

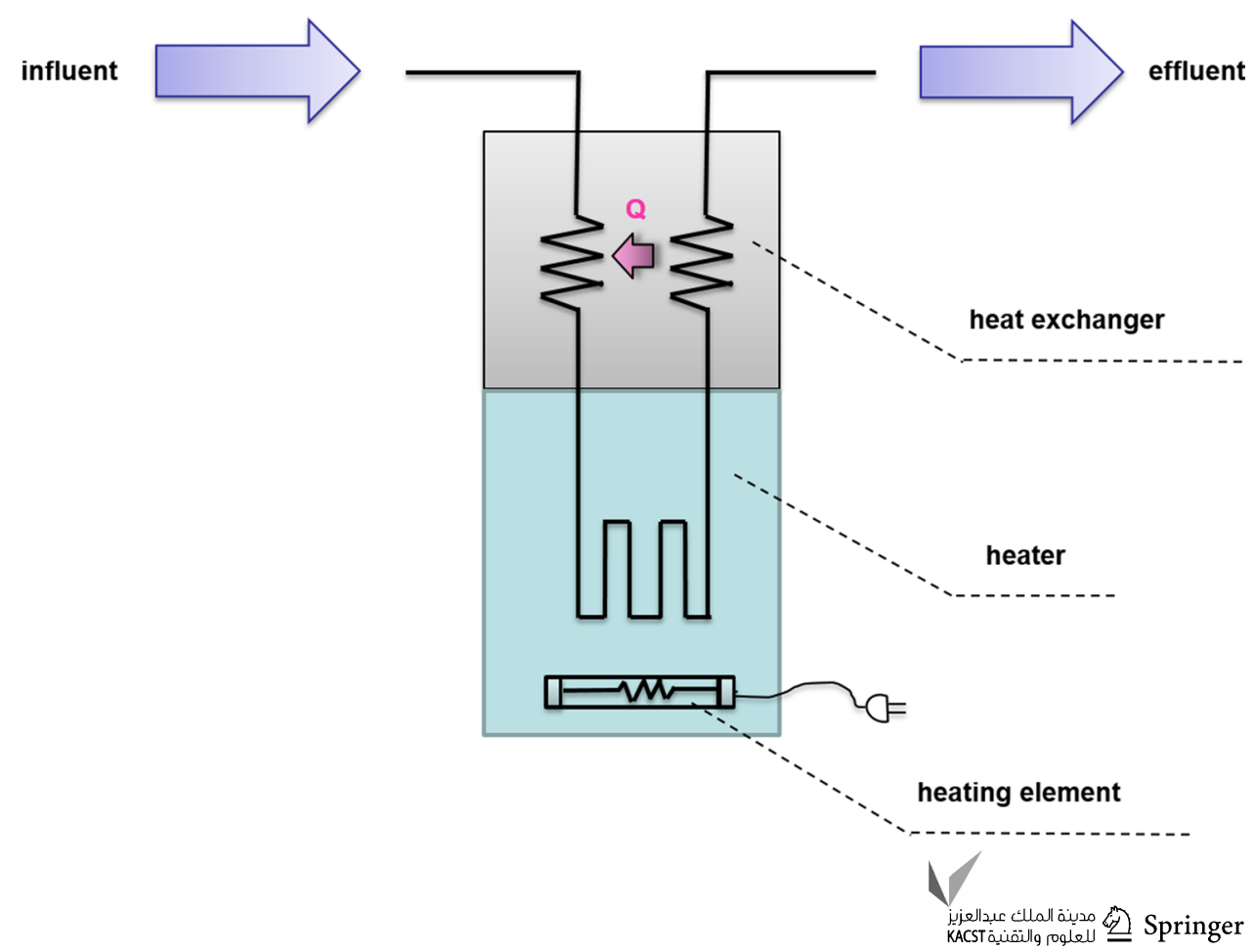




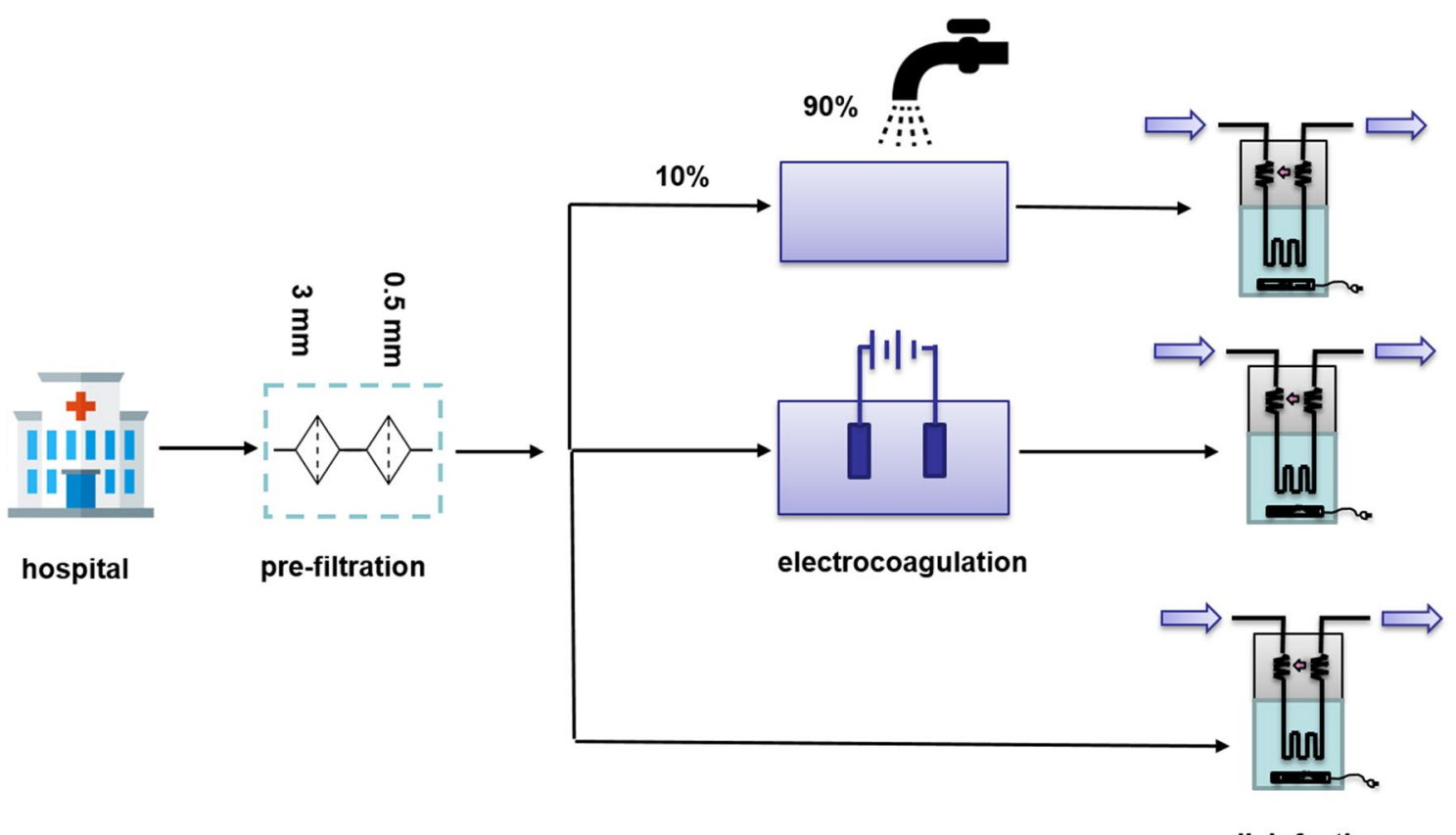

disinfection

Fig. 2 Schematic representation of the experimental setup

order of expected increasing turbidity: diluted wastewater, ECT wastewater and raw wastewater (Fig. 2).

Two types of analyses were performed for all pilot influents and effluents: microbiological and physical-chemical. In microbiological tests, quantifications of total colonyforming units (CFUs) were done by heterotrophic plate count method (APHA 2015) on PCA (standard medium used for assessment of the total viable bacterial growth) and UTI (used for identification and differentiation of microorganisms which cause urinary tract infections). All effluent CFU counts on PCA were performed by plating 1-mL undiluted sample aliquots directly on agar. To lower the detection threshold, prior to plating on UTI agar the effluent samples of $1500 \mathrm{~mL}$ were pre-concentrated by filtration with a pore size $0.45 \mu \mathrm{m}$ within $12 \mathrm{~h}$ of sampling. Milli-Q ultrapure filtered water was utilized as the control (Milli-Q "type-1," Merck). The next-generation sequencing (NGS) was performed in order to identify the most abundant bacterial species in the tested hospital wastewater.

The physical-chemical parameters were measured offline and included turbidity (HACH $2100 \mathrm{~N}$ turbidimeter), particle size distribution (PSD) (DIPA 2000 Analyzer), $\mathrm{pH}$ (HANNA multiparameter portable meter HI9828), electrical conductivity (EC) (HANNA multiparameter portable meter HI9828), dissolved oxygen (DO) (HANNA multiparameter portable meter HI9828), oxygen reduction potential (ORP) (HANNA multiparameter portable meter HI9828), total organic carbon (TOC) (TOC-L Shimadzu Total Organic Carbon Analyzer), biochemical oxygen demand $\left(\mathrm{BOD}_{5}\right)(\mathrm{WTW}$
Oxitop respirometric measuring system), chemical oxygen demand (COD) (HACH Lange LCK 314) as well as concentrations of $\mathrm{PO}_{4}-\mathrm{P}$ (HACH Lange 349), total nitrogen $\left(\mathrm{N}_{\mathrm{T}}\right)$ (HACH Lange LCK138), $\mathrm{NH}_{4}-\mathrm{N}$ (HACH Lange LCK303), $\mathrm{Cu}$ and $\mathrm{Fe}$ (Thermo Scientific iCAP-Q ICP-MS). Additionally, the temperature of the pilot influent and effluent was monitored during operation. Influent temperature was measured in the influent buffer tank, while effluent temperature was measured at the outlet pipe of the disinfection system. Fractionation of suspended solids into organics and inorganics was done according to standard methods (APHA 2015).

\section{Results and discussion}

The following section will present and discuss the results obtained during the experiments.

\section{Disinfection efficiency}

Total microbial counts determined for all wastewater streams were in the order of $10^{5} \mathrm{CFU} \mathrm{mL} \mathrm{mL}^{-1}$ on PCA and $10^{6}-10^{7} \mathrm{CFU} \mathrm{mL}^{-1}$ on UTI (Table 1). The ten most abundant species identified by NGS were: Aeromonas media, Streptococcus infantarius, Bifidobacterium thermophilum, Lactobacillus delbrueckii, Clostridium sticklandii, Acinetobacter baumannii, Bacteroides dorei, Bacteroides vulgatus, Streptococcus lutetiensis and Eubacterium rectale. 
Table 1 Concentrations of colony-forming units (CFU) found in the investigated wastewater streams

\begin{tabular}{lll}
\hline & $\begin{array}{l}\text { Total count PCA } \\
\left(\mathrm{CFU} \mathrm{mL} \mathrm{m}^{-1}\right)\end{array}$ & $\begin{array}{l}\text { Total } \\
\text { count UTI } \\
\left(\mathrm{CFU} \mathrm{mL} \mathrm{mL}^{-1}\right)\end{array}$ \\
\hline Diluted wastewater & $1.51 \times 10^{5}$ & $6.74 \times 10^{6}$ \\
ECT wastewater & $4.23 \times 10^{5}$ & $2.19 \times 10^{7}$ \\
Raw wastewater & $3.64 \times 10^{5}$ & $3.91 \times 10^{6}$ \\
\hline
\end{tabular}

Reduction in the total colony counts in the order of log $5-\log 8$ was confirmed for all wastewater streams, even when inlet turbidity reached 60-100 NTU (Fig. 3). Regarding colony counts on PCA, the reported disinfection level of $\log 5$ may be underestimated. This analysis was limited by the methodology, i.e., to enumerate $\mathrm{CFU}$ in effluents after disinfection $1 \mathrm{~mL}$ aliquots of undiluted sample were applied straight to agar plates. No colonies were counted after the incubation period.

To lower the detection threshold, effluent samples of $1500 \mathrm{~mL}$ were pre-concentrated by filtration prior to plating on UTI agar. In these samples, $30-300 \mathrm{CFU} \mathrm{mL}^{-1}$ was counted which corresponded to the achieved disinfection level of $\log 7-\log 8$.

The experiments were initially designed to increase the suspended solids content of the system influent in each subsequent experimental phase. However, as one can see in Fig. 3, turbidity, which is an indirect measure of the suspended solids, was the highest for wastewater pre-treated by electrocoagulation. The process of electrocoagulation can be used to remove, among other things, turbidity from wastewater (Bejjany et al. 2017; Chen 2004). Coagulants in the form of iron or aluminum hydroxides are generated in situ by oxidation of the anode material, and they destabilize particles present in the water leading to their aggregation (Ním et al. 2007). Aggregated solid particles can subsequently be separated from the bulk liquid by (electro)flotation or sedimentation. The results presented in Fig. 3 indicate that while electrocoagulation proceeded successfully, the subsequent process of solids separation failed.

\section{Effects on physical-chemical water quality}

To perform efficient disinfection, the pilot brings the treated water to high temperatures. As mentioned earlier, cold influent which enters the pilot is preheated by hot effluent leaving the pilot. The goal is not only to preheat the influent, but also to control the effluent temperature avoiding particularly high-temperature discharges and decreasing heat losses. This is especially important for cases where the disinfected water stream, e.g., WWTP effluent, is to be discharged to water bodies, such as a lake or a river, where changes in temperature may adversely affect aquatic life.

The plot presented in Fig. 4 exposes the analysis done to verify possible temperature differences between inlet and outlet for all the tested conditions. As it can be seen, effluents of the pilot were on average about $5-8{ }^{\circ} \mathrm{C}$ warmer than influents. Although European and American regulations do not specify the maximum temperatures allowable for thermal discharges, limits are set to the resulting temperature changes in the receiving water bodies, depending on their ecology (Raptis et al. 2016). In many US states, temperature of the receiving surface water must not exceed $32{ }^{\circ} \mathrm{C}$ (Madden et al. 2013), while in the European Union water temperature downstream from the discharge point must not be altered by more than $1.5^{\circ} \mathrm{C}$ for salmonid waters or by
Fig. 3 Log disinfection levels confirmed for wastewaters with different turbidity

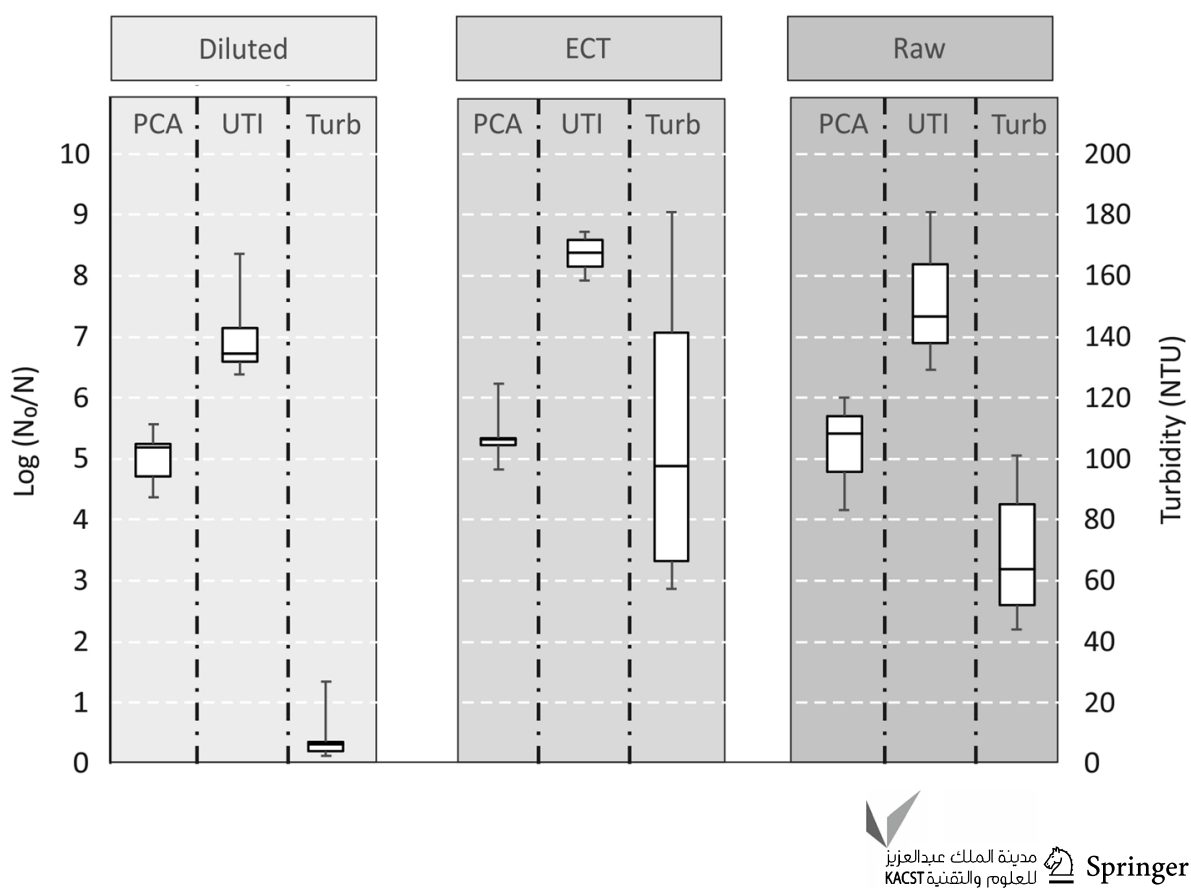




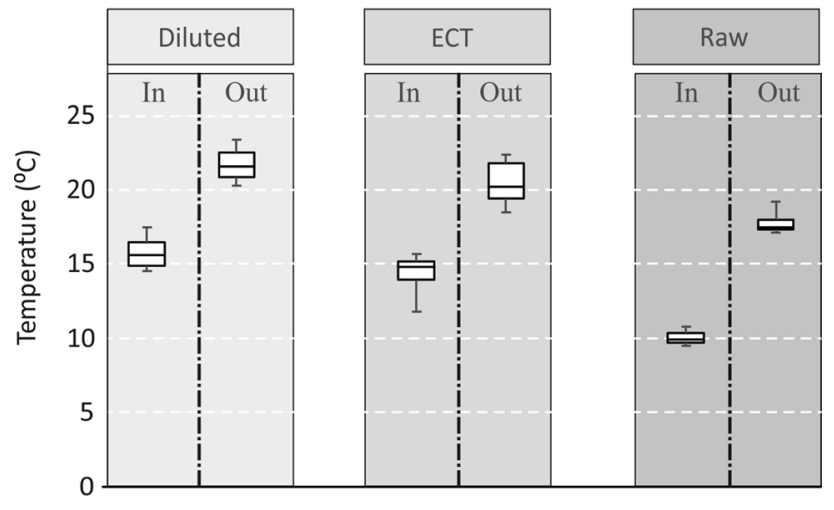

Fig. 4 Effects of the disinfection process on wastewater temperature

more than $3{ }^{\circ} \mathrm{C}$ for cyprinid waters (European Parliament and Council of the European Union 2006). Based on these limits and the volume/flow rate of the receiving water body, one can calculate the maximum amount of thermally treated water which can be discharged.

Particle size distribution (PSD) analysis performed on the influents and effluents of the pilot revealed that the investigated disinfection method was destructive and resulted in the shift in particle size from larger $(0-200 \mu \mathrm{m})$ to smaller $(0-60 \mu \mathrm{m})$ as shown in Fig. 5. This could be related to particle breakup caused by temperature and pressure shocks inside the pilot. A similar effect is observed during thermal pressure hydrolysis of waste activated sludge where high temperature and pressure conditions are used to disintegrate and partially solubilize the sludge (Pérez-Elvira et al. 2010; Phothilangka et al. 2008; Sapkaite et al. 2017).

As it can be seen in Fig. 5, even though the particle size population in the effluent shows rather small sizes, the population frequency has not drastically increased, which could be seen as an indication of mass imbalance, i.e., more mass in than out. This can be caused by two factors: (1) Firstly, colloids and organic particle aggregates such as fat or bacteria clusters, which will be detected in the influent count, might be solubilized under the action of high temperatures (Pérez-Elvira et al. 2010; Phothilangka et al. 2008; Sapkaite et al. 2017) and possibly volatized at the outlet; (2) secondly, the used analytical method (DIPA 2000) has a lower detection limit of 1-5 $\mu \mathrm{m}$; thus nanometric particles are not counted and therefore not visible. The latter hypothesis is particularly visible in Fig. 5a, where the effluent particle peaks seem to be cut in the lower size particles population.

In Fig. 5b, a large peak can be seen on the side of the size spectrum related to larger particles $(210-275 \mu \mathrm{m})$. This peak is discontinuous from the series of peaks related to the remaining, smaller particles in the sample (up to $120 \mu \mathrm{m}$ ). Also, the sizes represented by the large peak are bigger than the maximum particle size in the raw wastewater sample
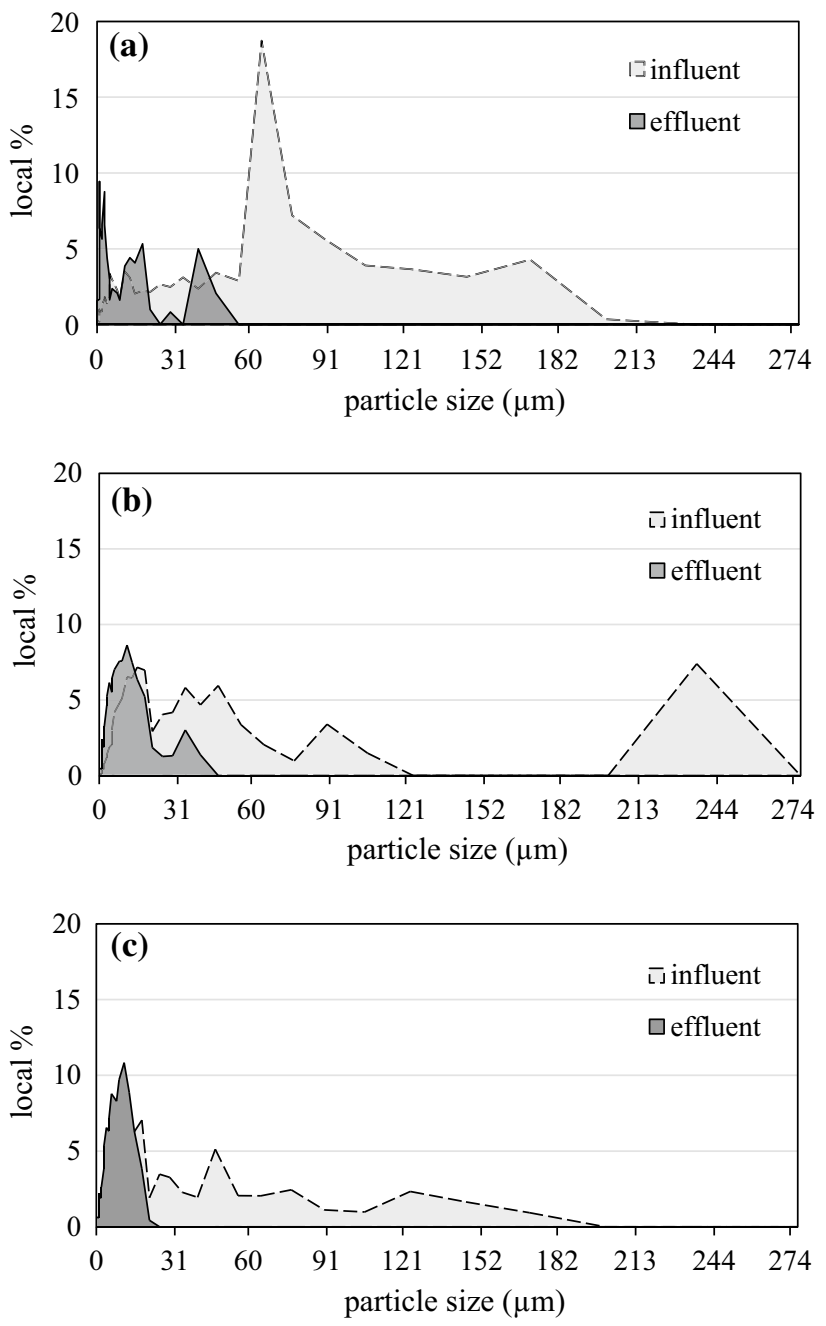

Fig. 5 Particle size distribution before (influent) and after (effluent) disinfection: a diluted wastewater, b ECT wastewater, c raw wastewater

(210 $\mu \mathrm{m}$, see Fig. 5c). This supports the aforementioned hypothesis that while electrocoagulation of wastewater succeeded in aggregating larger particles, the subsequent removal of the aggregates failed.

The results of other physical-chemical analyses are depicted graphically as box plots in Figs. 6 and 7. Such plots should be seen in the following way: (1) Big boxes represent great variability of the evaluated parameter, while small ones represent small variability; (2) the non-overlapping of the boxes points out toward possible statistically significant differences between two data sets; (3) dots are outliers.

Using Fig. 6 as a first indication for possible differences between the parameters tested in influents and effluents, one can see that TOC measured in ECT wastewater and raw wastewater (Fig. 6e), $\mathrm{BOD}_{5}$ in raw wastewater (Fig. 6f) as well as $\mathrm{COD}$ and $\mathrm{PO}_{4}-\mathrm{P}$ in all wastewater streams (Fig. 7a, 

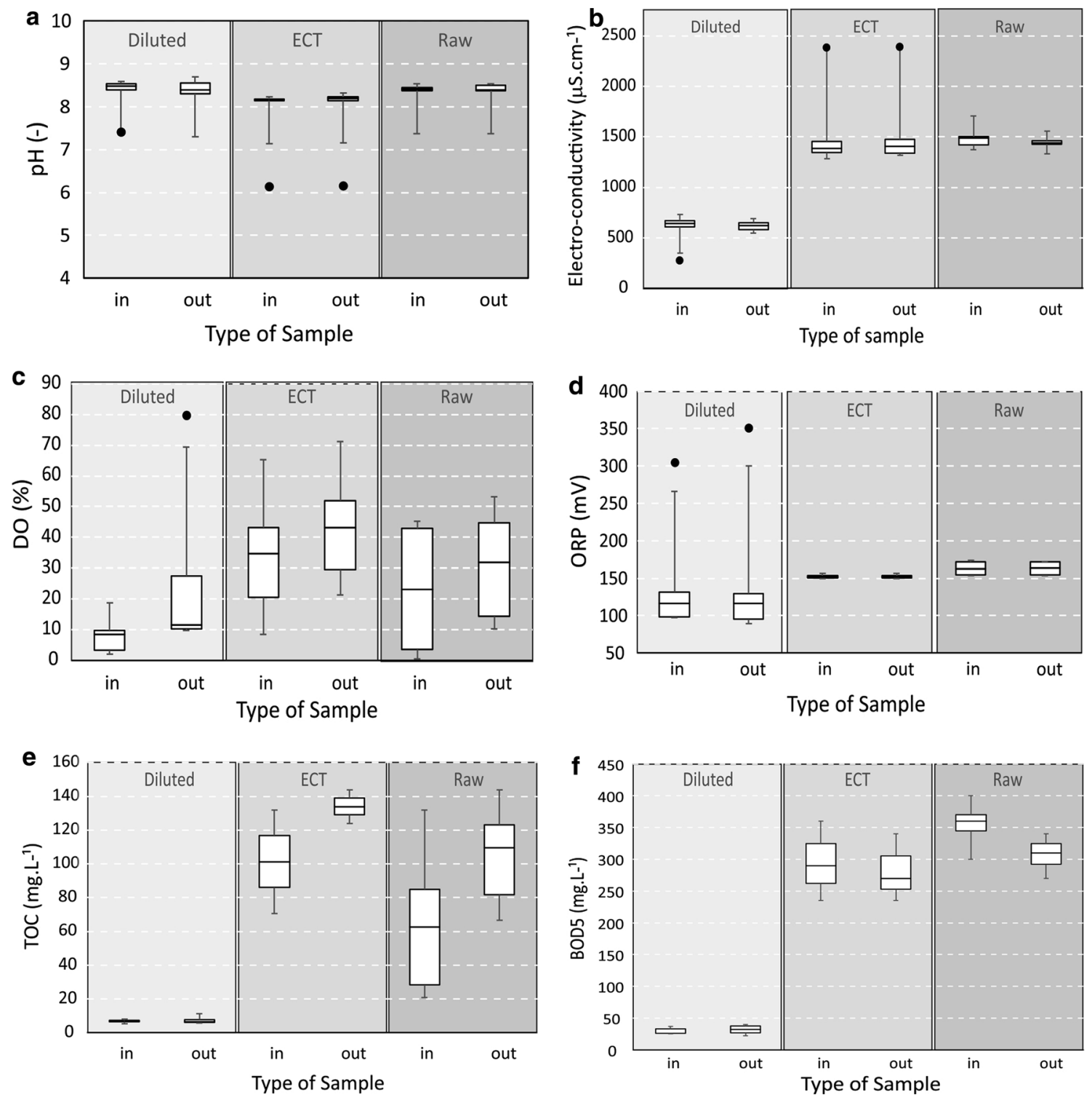

Fig. 6 Effects of the disinfection process on physical-chemical properties of wastewater

b, respectively) are the parameters which might have been affected by the disinfection process.

To further verify this assumption, the above-mentioned parameters were compared with $95 \%$ confidence interval hypothesis tests for different averages, i.e., null hypothesis $\mathrm{H}_{0}: \mu_{1}=\mu_{2}$. The results pointed out that the concentrations of TOC in raw wastewater and $\mathrm{PO}_{4}-\mathrm{P}$ concentrations in all wastewater streams were statistically different $\left(\mathrm{H}_{0}\right.$ rejected) before and after disinfection.

In the case of TOC concentrations in real wastewater, the values measured in the effluent were on average $67 \%$ higher than the values measured in the influent. This result might be related to the already discussed shift in PSD (Fig. 5) and the fact that the method used for TOC analysis required a prefiltration of the analyzed samples with $0.45-\mu \mathrm{m}$ membrane.
As shown in Fig. 5, the maximum size of particles present in raw wastewater decreased from $210 \mu \mathrm{m}$ before disinfection to $21 \mu \mathrm{m}$ after disinfection. When samples of the pilot influent, i.e., before disinfection, were analyzed, the TOC fraction related to organic matter particles or their clusters larger than $0.45 \mu \mathrm{m}$ was retained on the membrane during the pre-filtration step and therefore not measured. In the case of the pilot effluent, i.e., after disinfection, a larger fraction of particles present in the samples passed through the membrane and the related TOC was subsequently measured. Thus, despite the differences in TOC measured before and after disinfection of raw wastewater, it is expected that the total content of organic matter remained unchanged. This hypothesis is supported by the results of TOC measurements in diluted and electrocoagulation-treated wastewater as well 
Fig. 7 Effects of the disinfection process on the concentration and speciation of organics $(\mathrm{COD})$ and nutrients $(\mathrm{N}, \mathrm{P})$ in the treated wastewater
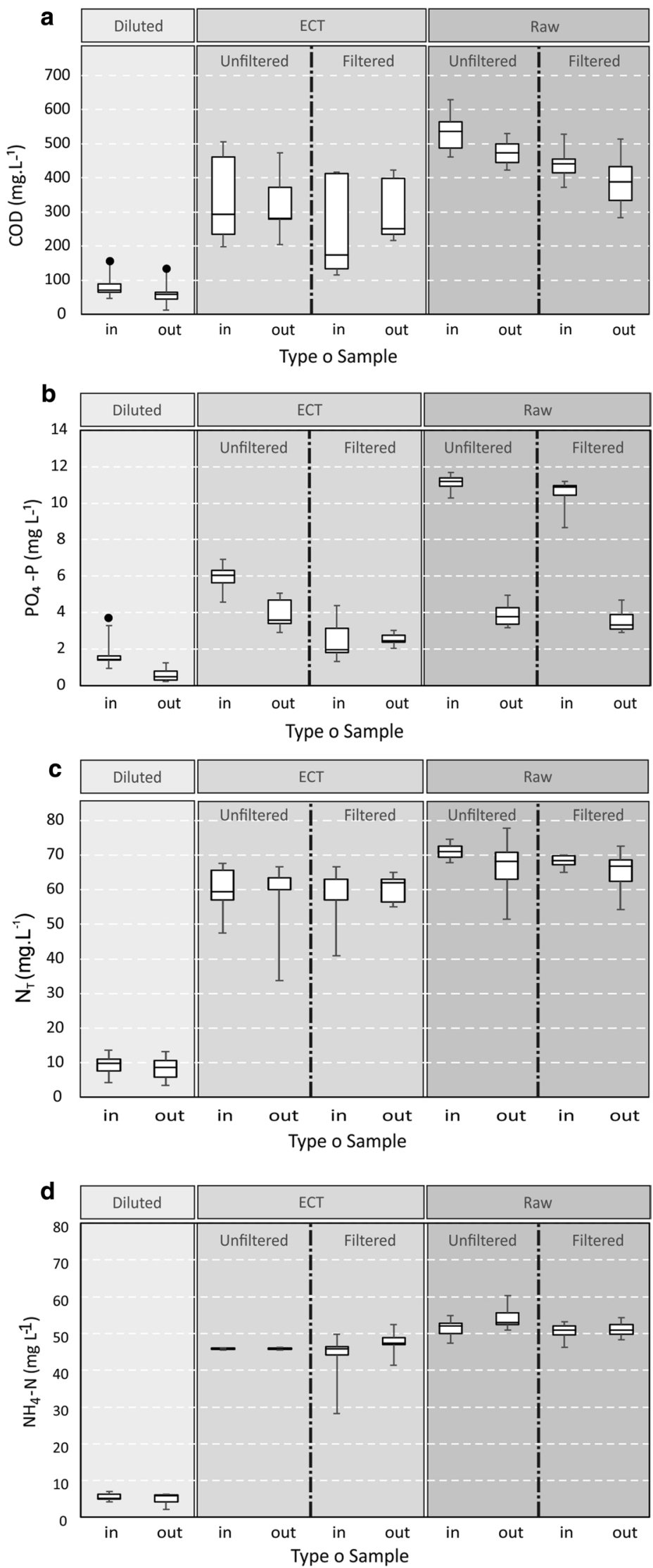
as by the results of COD measurements. COD is another parameter which describes the content of organic material in analyzed samples, and it does not require a pre-filtration step. For all wastewater streams, the values of COD measured before and after disinfection did not differ statistically.

Regarding $\mathrm{PO}_{4}-\mathrm{P}$, the average concentrations measured in the effluents were lower than those measured in the influents by $65 \%, 33 \%$ and $65 \%$ for diluted, ECT and raw wastewater, respectively. A possible reason for that may be complexation of $\mathrm{PO}_{4}-\mathrm{P}$, e.g., with $\mathrm{Fe}$ present in the treated water, followed by coagulation and precipitation (Korving et al. 2019; Sedlak 2018; Seida and Nakano 2002). Further, $\mathrm{PO}_{4}-\mathrm{P}$ concentration measured in the ECT wastewater was almost two times lower than the concentration measured in raw wastewater. This can be attributed to $\mathrm{PO}_{4}-\mathrm{P}$ coagulation and precipitation in the electrocoagulation step (Attour et al. 2014).

To get a better insight into the effects of disinfection on the distribution of $\mathrm{COD}, \mathrm{PO}_{4}-\mathrm{P}, \mathrm{N}_{\mathrm{T}}$ and $\mathrm{NH}_{4}-\mathrm{N}$, during experiments with ECT wastewater and raw wastewater those parameters were differentiated into two fractions: total (including suspended, colloidal and dissolved fraction) and filtered (which included colloidal and soluble fractions) (Fig. 7).

Only in the case of $\mathrm{PO}_{4}-\mathrm{P}$ in ECT wastewater, the concentrations in the colloidal and dissolved fractions differed from the total concentration. In this experimental phase, 57\% of the $\mathrm{PO}_{4}-\mathrm{P}$ present in the system influent and $35 \%$ of the $\mathrm{PO}_{4}-\mathrm{P}$ present in the system effluent were attributed to the suspended fraction.

The lower values of $\mathrm{PO}_{4}-\mathrm{P}$ can also be related to possible alteration of organic molecules during disinfection. A short investigation was done with raw wastewater to verify how organic compounds (here represented by volatile suspended solids, VSS) and inorganics (represented by stable solids, i.e., ashes) change during the disinfection process. The results presented in Fig. 8 show a significant reduction in organics after the treatment, while the inorganics remained rather stable. Further investigations have, however, to be

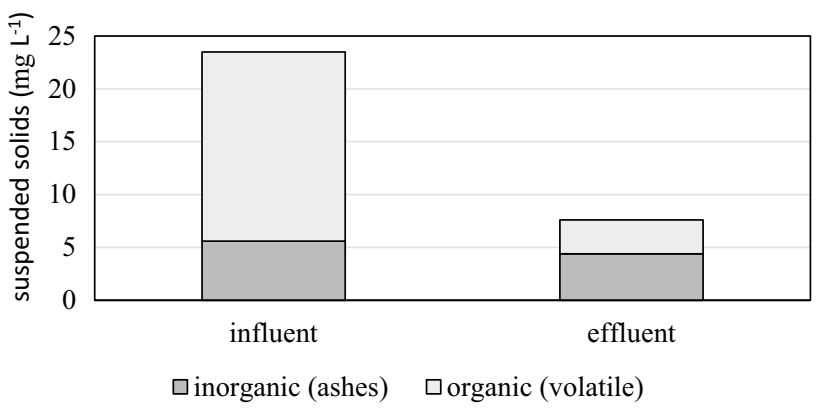

Fig. 8 Concentrations of suspended organic and inorganic solids before and after thermal disinfection of raw wastewater performed, in order to better correlate these results with the decrease in $\mathrm{P}$ concentration.

\section{Fate of heavy metals}

$\mathrm{Cu}$ concentrations were measured to verify the possible migration from the heat exchanger coil into the treated water. Results showed an increase in the concentration of this element from $6-50 \mu \mathrm{g} \mathrm{L}^{-1}$ in the pilot influents to $100-447 \mu \mathrm{g} \mathrm{L}^{-1}$ in the effluents (Table 2). However, $\mathrm{Cu}$ concentrations always remained below the WHO guideline for drinking water $\left(2000 \mu \mathrm{g} \mathrm{L}^{-1}\right)$ (WHO 2017) and below the Maximum Contaminant Level Goal (MCLG) established by the US Environmental Protection Agency (1300 ppb) (EPA 2014). Such contamination was expected given the fact that the heat exchanger is a copper coil, but, in extreme cases, where the presence of such contaminant is not acceptable at the encountered levels, it is recommended to consider using a more stable metal.

$\mathrm{Fe}$ concentrations were measured because of their relationship with electrocoagulation (sacrificial $\mathrm{Fe}$ anode) and potential $\mathrm{PO}_{4}-\mathrm{P}$ removal. In the experiments with ECT wastewater elevated Fe concentrations $\left(>500 \mu \mathrm{g} \mathrm{L}{ }^{-1}\right)$ were measured both before (influent) and after (effluent) the disinfection. Those high concentrations can be attributed to the electrodissolution of the Fe anode. Further, Fe concentrations measured in the system effluents were lower than the concentration in influents. This corroborates with the aforementioned possibility that $\mathrm{Fe}$ and $\mathrm{PO}_{4}-\mathrm{P}$ present in wastewater formed insoluble complexes which coagulated and precipitated, resulting in the lowering of concentrations of those chemical species in the bulk liquid.

\section{Energy consumption}

A crucial aspect of thermal disinfection systems is the energy $/ \mathrm{m}^{3}$ of treated water aspect ratio. Such aspect ratio is rather challenging to define when comparing different disinfection systems, because it has also to be related to the log disinfection capability of the system; therefore, it is rather variable depending on the inlet contamination level. Another consideration is the fact that the proposed system can work with high turbidity effluent, which by

Table 2 Concentrations of $\mathrm{Cu}$ and $\mathrm{Fe}$ measured in the pilot influents and effluents

\begin{tabular}{lcllll}
\hline & \multicolumn{2}{c}{$\mathrm{Cu}\left(\mu \mathrm{L} \mathrm{L}^{-1}\right)$} & & $\mathrm{Fe}\left(\mu \mathrm{g} \mathrm{L} \mathrm{L}^{-1}\right)$ \\
\cline { 2 - 3 } & Influent & Effluent & & Influent & Effluent \\
\hline Diluted wastewater & $6 \pm 4$ & $119 \pm 37$ & & $41 \pm 29$ & $<5$ \\
ECT wastewater & $21 \pm 23$ & $150 \pm 109$ & & $>500$ & $>500$ \\
Raw wastewater & $54 \pm 10$ & $381 \pm 432$ & & $380 \pm 54$ & $231 \pm 90$ \\
\hline
\end{tabular}


Table 3 Comparison of energy demand for water disinfection by UV irradiation, chlorination and thermal inactivation

\begin{tabular}{|c|c|c|c|}
\hline & Source & $\begin{array}{l}\text { Energy demand } \\
\left(\mathrm{W} \mathrm{h} \mathrm{L} \mathrm{L}^{-1}\right)\end{array}$ & Disinfection level \\
\hline Low-pressure UV lamps & E3T (2018) & $0.4-0.9$ & $\log 2-\log 4$ \\
\hline Medium-pressure UV lamps & E3T (2018) & $1.7-2.1$ & $\log 2-\log 4$ \\
\hline $\mathrm{Cl}_{2}$ gas system & E3T (2018) & $0.2-0.9$ & $\log 2-\log 4$ \\
\hline $\begin{array}{l}\text { Thermal disinfection of recircu- } \\
\text { lation water in horticulture }\end{array}$ & STOWA (2007) & 9.3 & $\log 3$ \\
\hline Investigated pilot & $\begin{array}{l}\text { Bowen H2O Technology, Inc., } \\
\text { personal communication (2018) }\end{array}$ & $<10$ & $\log 6-\log 8$ \\
\hline
\end{tabular}

its turn excludes the necessity of a pre-treatment step for suspended solids removal. In conventional disinfection systems, given the fact that turbidity drastically affects the process efficiency, such costs have to be incorporated.

Even though a thorough energy analysis was not seen as the main scope of this work, a search of professional literature was performed to get an insight into how thermal disinfection compares to the two most commonly applied technologies, i.e., chlorination and UV irradiation. The results are presented in Table 3.

As it can be seen, the studied system is still in the higher energy demand level when compared to conventional systems. However, as also shown in Table 3, the presented system both provides higher log disinfection and excludes the necessity of a pre-treatment to remove turbidity. A simple calculation can be presented if considered, for example, an ultrafiltration system used as a pre-treatment step to remove turbidity, followed by a disinfection (chlorination) tank. Such systems normally present energy consumption values of $1.5 \mathrm{~kW} \mathrm{~h} \mathrm{~m}^{-3}$ (Berghof Membranes, personal communication 2019). From this value, it is possible to see that such pre-treatment can double the energy use of conventional disinfection systems. Nevertheless, it will still operate at half the consumption level of the system studied here. Again, it is important to stress that (1) the $\log$ disinfection level achieved with the studied system is much higher, (2) the study done here was not intended to optimize energy consumption (further studies will follow touching upon this point) and (3) WWTP cogeneration and investment in green energy as well as strategic locations (oil refineries, incinerators, solar power, etc.) could provide the required heat or energy to make the system energetically compatible. Moreover, in certain locations and/ or circumstances, such as poor regions and areas struck by natural disasters, filtration is often unavailable and quick actions are extremely necessary.

\section{Conclusions}

The following conclusions can be inferred from the abovepresented work:

- Overall performance of the system shows up to $\log 8$ disinfection level with influent turbidity as high as 100 NTU.

- The following physical-chemical parameters were unaltered during the disinfection processes: $\mathrm{pH}$, electrical conductivity, DO, TOC, ORP, $\mathrm{BOD}_{5}, \mathrm{COD}, \mathrm{N}_{\mathrm{T}}$ and $\mathrm{NH}_{4}-\mathrm{N}$.

- Particle count analysis has shown that the applied high temperature and pressure cause particle destruction as the outlet population presents much smaller sizes than the inlet population.

- Particle size analysis and solids analysis indicated dissolution of organics in the liquid phase.

- $\mathrm{PO}_{4}-\mathrm{P}$ analysis indicated a reduction in its concentration for all tested influents, the highest reduction being seen in the ECT effluent. The reduction observed in the diluted and raw influent is related to organic dissolution, and the (extra) reduction observed for the ECT influent is attributed to complexation with iron species.

- Temperature measurements indicated a $5-8{ }^{\circ} \mathrm{C}$ increase in effluent temperature.

- Metal analysis indicated migration of copper ions from the heating element.

- More research must be conducted to further optimize the system's energy consumption. Preliminary numbers have indicated consumption of around $10 \mathrm{~W} \mathrm{~h} \mathrm{~L}^{-1}$, thus comparable with commercially available systems.

\section{Compliance with ethical standards}

Conflict of interest The authors declare that they have no conflict of interest. 
Open Access This article is licensed under a Creative Commons Attribution 4.0 International License, which permits use, sharing, adaptation, distribution and reproduction in any medium or format, as long as you give appropriate credit to the original author(s) and the source, provide a link to the Creative Commons licence, and indicate if changes were made. The images or other third party material in this article are included in the article's Creative Commons licence, unless indicated otherwise in a credit line to the material. If material is not included in the article's Creative Commons licence and your intended use is not permitted by statutory regulation or exceeds the permitted use, you will need to obtain permission directly from the copyright holder. To view a copy of this licence, visit http://creativecommons.org/licenses/by/4.0/.

\section{References}

Abraham JP, Plourde BD, Minkowycz WJ (2015) Continuous flow solar-thermal pasteurization of drinking water: methods, devices, microbiology, and analysis. Renew Energy 81:795-803

Al-Gheethi AAS, Ismail N, Lalung J, Talib A, Ab. Kadir MO (2013) Reduction of faecal indicators and elimination of pathogens from sewage treated effluents by heat treatment. CJASR 2:39-55

Al-Gheethi AA, Efaq AN, Bala JD, Norli I, Abdel-Monem MO, Ab. Kadir MO (2018) Removal of pathogenic bacteria from sewagetreated effluent and biosolids for agricultural purposes. Appl Water Sci 8:74

APHA (2015) Standard methods for the examination of water and wastewater. American Public Health Association (APHA), American Water Works Association (AWWA), Water Environment Federation (WEF), Washington, DC

Attour A, Touati M, Tlili M, Ben Amor M, Lapicque F, Leclerc JP (2014) Influence of operating parameters on phosphate removal from water by electrocoagulatin using aluminum electrodes. Sep Purif Technol 123:124-129

Backer HD (1996) Effect of heat on the sterilization of artificially contaminated water. J Travel Med 3:1-4

Basu M, Ghosh S, Jana A, Bandyopadhyay S, Singh R (2017) Resource mapping during a natural disaster: a case study on the $2015 \mathrm{Nepal}$ earthquake. Int J Disast Risk Reduct 24:24-31

Batra N, Sehgal B, Mehta M (2018) Awareness of water borne diseases and water purification practices at household level. IJHW 9:580-583

Bejjany B, Lekhlif B, Eddaqaq F, Dani A, Mellouk H, Digua K (2017) Treatment of the surface water by electrocoagulation-electroflotation process in internal loop airlift reactor: conductivity effect on turbidity removal and energy consumption. JMES 8:2757-2768

Braekeveld E, Lau BP, Tague B, Popovic S, Tittlemier SA (2011) Effect of cooking on concentrations of $\beta$-estradiol and metabolites in model matrices and beef. J Agric Food Chem 59:915-920

Chawaga $P$ (2015) Is pasteurization the key to water reuse? Water Online. https://www.wateronline.com/doc/is-pasteurization-thekey-to-water-reuse-0001 Accessed 16 Dec 2019

Chen G (2004) Electrochemical technologies in wastewater treatment. Sep Purif Technol 38:11-41

Corradini MG, Normand MD, Peleg M (2007) Modelling non-isothermal heat inactivation of microorganisms having biphasic isothermal survival curves. Int J Food Microbiol 116:391-399

Cox T (2013) Wastewater disinfection pioneer, Pasteurization Technology Group, receives prestigious water technology award. Water Online. https://www.wateronline.com/doc/wastewater-disinfecti on-pasteurization-prestigious-water-award-0001 Accessed 16 Dec 2019

Currier RW, Widness JA (2018) A brief history of milk hygiene and its impact on infant mortality from 1875 to 1925 and implications for today: a review. J Food Prot 81:1713-1722
Du Y, Lv XT, Wu QY, Zhang DY, Zhou YT, Peng L, Hu HY (2017) Formation and control of disinfection byproducts and toxicity during reclaimed water chlorination: a review. J Environ Sci 58:51-63

E3T (2018) Energy efficiency emerging technologies program, Washington State University. http://e3tnw.org. Accessed Apr 2018

EPA (2011) Water treatment manual: disinfection, 2nd ed. Environemntal Protection Agency, Wexford. https://www.epa.ie/pubs/advice/ drinkingwater/Disinfection2_web.pdf Accessed 16 Dec 2019

EPA (2014) Drinking water contaminants. United States Environmental Protection Agency (EPA) http://water.epa.gov/drink/contaminan ts/\#one. Accessed 16 Dec 2019

Ericsson CD, Steffen R, Backer H (2002) Water disinfection for international and wilderness travelers. Clin Infect Dis 34:355-364

European Parliament and Council of the European Union (2006) Directive 2006/44/EC of the European Parliament and Council on the quality of fresh waters needing protection or improvement in order to protect fish life

Farrel C, Hassard F, Jefferson B, Leziart T, Nocker A, Jarvis P (2018) Turbidity composition and the relationship with microbial attachment and UV inactivation efficacy. Sci Total Environ 624:638-647

Garnier M, Harper DM, Blaskovicova L, Hancz G, Janauer GA, Jolánkai Z, Lanz E, Lo Porto A, Mándoki M, Pataki B, Rahuel JL, Robinson VJ, Stoate C, Tóth E, Jolánkai G (2015) Climate change and European water bodies, a review of existing gaps and future research needs: findings of the Climate Water Project. Environ Manag 56:271-285

GBD 2016 Diarrhoeal Disease Collaborators (2018) Estimates of the global, regional and national morbidity, mortality and aetiologies of diarrhoea in 195 countries: a systematic analysis for the Global Burden of Disease Study 2016. Lancet Infect Dis 18:1211-1228

Godwin A, McBurnett M (eds) (2016) Pasteurization process generates energy and water. Wastewater Technology. https://www.water techonline.com/wastewater/article/16210825/pasteurization-proce ss-generates-energy-and-water Accessed 16 Dec 2019

Hatami H (2013) The importance of water and water-borne diseases: on occasion of the World Water day. Int J Prev Med 4:243-245

Heshmati A (2015) Impact of cooking procedures on antibacterial drug residues in food: a review. JFQHC 2:33-37

Keegan A, Wati S, Robinson B (2012) Chlor(am)ine disinfection of human pathogenic viruses in recycled waters (SWF 62M-2114). Smart Water Fund. https://www.clearwatervic.com.au/user-data/ research-projects/swf-files/62m-2114-chlorine-disinfection-ofhuman-pathogenic-viruses-_final_report.pdf Accessed 16 Dec 2019

Khayan K, Husodo AH, Astuti I, Sudarmadji S, Djohan TS (2019) Rainwater as a source of drinking water: health impacts and rainwater treatment. J Environ Public Health 2019, article ID 1760950

Kollu K, Örmeci B (2012) Effect of particles and bioflocculation on ultraviolet disinfection of Escherichia coli. Water Res 46:750-760

Korving L, van Loodsrecht M, Wilfert P (2019) Effect or iron on phosphate recovery from sewage sludge. In: Ohtake $\mathrm{H}$, Tsuneda $\mathrm{S}$ (eds) Phosphorus recovery and recycling. Springer, Singapore

Lavrnić S, Zapater-Pereyra M, Mancini ML (2017) Water scarcity and wastewater reuse standards in Southern Europe: focus on agriculture. Water Air Soil Pollut 228:251

Lechevallier MW, Evans TM, Seidler RJ (1981) Effect of turbidity on chlorination efficiency and bacterial persistence in drinking water. Appl Environ Microbiol 42:159-167

Lee JY, Kim H, Han M (2016) Importance of maintenance in rainwater harvesting systems: a case study. Water Supply 16:97-103

Léziart T, Dutheil de la Rochere PM, Cheswick R, Jarvis P, Nocker A (2019) Effect of turbidity on water disinfection by chlorination with the emphasis on humic acids and chalk. Environ Technol 40:1734-1743

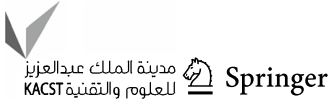


Li XF, Mitch WA (2018) Drinking water disinfection byproducts (DBPs) and human health effects: multidisciplinary challenges and opportunities. Environ Sci Technol 52:1681-1689

Madden N, Lewis A, Davis M (2013) Thermal effluent from the power sector: an analysis of once-through cooling system impacts on surface water temperature. Environ Res Lett 8:035006

Metcalf and Eddy (2014) Wastewater engineering: treatment and resource recovery, 5th edn. McGraw-Hill, New York

Misra AK, Singh V (2012) A delay mathematical model for the spread and control of water borne diseases. J Theor Biol 301:49-56

Mocé-Llivina L, Muniesa M, Pimenta-Vale H, Lucena F, Jofre J (2003) Survival of bacterial indicator species and bacteriophages after thermal treatment of sludge and sewage. Appl Environ Microbiol 69:1452-1456

Morais RL, Santiago MF, Zang JW, Fonseca-Zang WA, Schmidt F (2018) Removal of synthetic sex hormones by hydrothermal carbonization. An Acad Bras Ciênc 90:1327-1336

Newman SE (2004) Disinfecting irrigation water for disease management. In: 20th Annual conference on pest management on ornamentals, Society of American Florists, San Jose, CA

Ním MF, Othman F, Sohaili J, Fauzia Z (2007) Removal of COD and turbidity to improve wastewater quality using electrocoagulation technique. MJAS 11:198-205

Orlikowski LB, Treder W, Ptaszek M, Trzewik A, Kowalczyk W, Łazęcka U (2017) Necessity of disinfecting water for crop irrigation. Infrastructure an Ecology of Rural Areas, No IV/1/2017, Polish Academy of Sciences, Cracow Branch, pp 1386-1400

Parry JV, Mortimer PP (1984) The heat sensitivity of hepatitis A virus determined by a simple tissue culture method. J Med Virol $14: 277-283$

Pérez-Elvira SI, Fdz-Polanco M, Fd-Polanco F (2010) Increasing the performance of anaerobic digestion: pilot scale experimental study for thermal hydrolysis of mixed sludge. Front Environ Sci Eng 4:134-141

Phothilangka P, Schoen MA, Huber M, Luchetta P, Winkler T, Wett B (2008) Prediction of thermal hydrolysis pretreatment on anaerobic digestion of waste activated sludge. Water Sci Technol 58:1467-1473

Pirsaheb M, Sharafi K, Ahmadi E, Moradi M (2017) Prevalence of the waterborne diseases (diarrhea, dysyntery, typhoid and hepatitis A) in West of Iran during 5 years (2006-2010). Ann Trop Med PH 10:1524-1528

Plourde BD, Gikling A, Marsch T, Riemenschneider MA, Fitzgerald JL, Minkowycz WJ, Kiplagat J, Abraham JP (2019) Design and evaluation of a concentrated solar-powered thermal pasteurization system. J Solar Energy Res Updates 6:34-42

Pullman GS, DeVay JE, Garber RH (1981) Soil solarization and thermal death: a logarithmic relationship between time and temperature for four soilborne plant pathogens. Dis Control Pest Manag 71:959-964

Raptis CE, van Vliet MTH, Pfister S (2016) Global thermal pollution f rivers from thermoelectric power plants. Environ Res Lett 11:104011

Reyneke B, Dobrowsky PH, Ndlovu T, Khan W (2016) EMA-qPCR to monitor the efficiency of a closed-coupled solar pasteurization system in reducing Legionella contamination of roof-harvested rainwater. Sci Total Environ 553:662-670

Runia WT, Amsing JJ (2001) Disinfection of recirculation water from closed cultivation systems by heat treatment. ISHS Acta Horticulturae 548: International Symposium on Growing Media and Hydroponics
Sapkaite I, Barrado E, Fdz-Polanco F, Pérez-Elvira SI (2017) Optimization of a thermal hydrolysis process for sludge pre-treatment. J Environ Manag 192:25-30

Sarkar R, Vogt J (2015) Drinking water vulnerability in rural coastal areas of Bangladesh during and after natural extreme events. Int J Disast Risk Reduct 14:411-423

Sedlak R (2018) Principles of chemical phosphate removal. In: Municipal wastewater, principles and practise, 2 nd ed

Seida Y, Nakano Y (2002) Removal of phosphate by layered double hydroxides containing iron. Water Res 36:1306-1312

Smelt JPPM, Brul S (2014) Thermal inactivation of microorganisms. Crit Rev Food Sci Nutr 54:1371-1385

Śmiech KM, Kovács T, Wildschut RF, Criado Monleon AJ, de VriesOnclin B, Bowen JG, Agostinho LLF (2018) Thermal disinfection of hospital wastewater in a pilot-scale continuous-flow system. In: Conference presentation: 10th Eastern European young water professionals conference IWA YWP, 7-8 May 2018, Zagreb, Croatia

Spinks AT, Dunstan RH, Harrison T, Coombes P, Kuczera G (2006) Thermal inactivatin of water-borne pathogenic and indicator bacteria at sub-boiling temperatures. Water Res 40:1326-1332

STOWA (2007) KASZA—kas zonder afvalwater. Rapport 28/2007, Utrecht, The Netherlands

Thornton G, Prentice R, Watson M (2006) The safe reuse of water using heat disinfection. In: Conference paper Enviro 06, Melbourne, Australia

Tian L, Khalil S, Bayen S (2017) Effect of thermal treatments on the degradation of anibiotic residues in food. Crit Rev Food Sci Nutr 57:3760-3770

Tram Vo P, Ngo HH, Guo W, Zhou J, Nguyen PD, Listowski A, Wang XC (2014) A mini-review on the impacts of climate change on wastewater reclamation and reuse. Sci Total Environ 494-495:9-17

Tripanagnostopoulos Y, Rocamora MC (2007) Use of solar thermal collectors for disinfection of greenhouse hydroponic water. In: ISHS Acta Horticulturae 801: international symposium on high technology for greenhouse system management: Greensys 2007

UNICEF and WHO (2019) Progress on household drinking water, sanitation and hygiene 2000-2017. Special Focus on Inequalities. United Nations Children's Fund (UNICEF) and World Health Organization, New York

United Nations (2010) Sustainable development goals. https://susta inabledevelopment.un.org/. Accessed 16 Dec 2019

Watts S (2016) A mini review on technique of milk pasteurization. J Pharmacogn Phytochem 5:99-101

WHO (2017) Guidlines for drinking-water quality, 4th edn. Incorporating the 1st addendum. World Health Organization

WHO (2019) Drinking water factsheets. World Health Organization. https://www.who.int/news-room/fact-sheets/detail/drinking-water Accessed 16 Dec 2019

Winward GP, Avery LM, Stephenson T, Jefferson B (2008) Chlorine disinfection of greywater for reuse: effect of organics and particles. Water Res 42:483-491

Publisher's Note Springer Nature remains neutral with regard to jurisdictional claims in published maps and institutional affiliations. 